\title{
EFFECTS OF COLOURED SHADE NETTING ON THE VEGETATIVE DEVELOPMENT AND LEAF STRUCTURE OF OCIMUM SELLOI $\left.\mathbf{(}^{1}\right)$
}

\author{
LARISSA CORREAA DO BOMFIM COSTA $\left({ }^{2 *}\right)$, JOSÉ EDUARDO BRASIL PEREIRA PINTO $\left({ }^{3}\right)$, \\ EVARISTO MAURO DE CASTRO $\left({ }^{3}\right)$, EDUARDO ALVES $\left({ }^{3}\right)$, \\ SUZAN KELLY VILELA BERTOLUCCI $\left({ }^{3}\right)$, LOUISE FERREIRA ROSAL $\left({ }^{3}\right)$
}

\begin{abstract}
The objective of this work was to investigate the effects of shading on the growth and development of the medicinal plant Ocimum selloi after 90 days. Seedlings were maintained under three different light treatments, namely, full sunlight $v$ s coloured shade treatments provided by red and blue ChromatiNet ${ }^{\circledR}$ $50 \%$ coloured netting. After 90 days of cultivation, height, stem diameter, petiole length, total leaf area (TLA), specific leaf area (SLA), leaf area ratio (LAR) and leaf weight ratio (LWR) of each plant hare measured. Microscopic examination of leaf sections were conducted in order to determine the leaf blade thicknesses, together with the size and density of the stomata, the number and area of chloroplasts, and chloroplast starch grains present in the palisade parenchyma cells. Although coloured shade-grown plants were taller in comparison with those grown in full sunlight, total dry biomass together with root, stem and leaf tissue biomasses were lower. Plants exhibited phenotypic plasticity, as demonstrated by the different TLA, SLA, LAR and LWR values that were recorded under the various light treatments. Stomatal density and leaf thickness was increased in plants maintained in full sunlight owing to the expansion of the abaxial epidermis and the spongy parenchyma. Chloroplasts were more numerous and larger in plants grown under shading, whilst the accumulation of chloroplastic starch grains was greater in plants grown under red shading or in full sunlight.
\end{abstract}

Key words: light quality and intensity; plastic coloured netting; plant anatomy; leaf morphology and structure.

\section{RESUMO}

\section{EFEITO DO SOMBREAMENTO COM TELAS COLORIDAS NO DESENVOLVIMENTO VEGETATIVO E ESTRUTURA FOLIAR DE Ocimum selloi}

\begin{abstract}
O objetivo deste trabalho foi verificar o efeito do sombreamento de Ocimum selloi com telas coloridas do tipo Cromatinet ${ }^{\circledR}(50 \%)$ vermelha, azul e a condição natural de pleno sol (sem tela) sobre as características biométricas, fisiológicas, anatômicas e ultraestruturais da planta após 90 dias. As plantas nas telas coloridas tiveram maior crescimento em altura, mas o maior acúmulo de biomassa seca total e particionada e relação raiz: parte aérea (R:PA) ocorreram na condição de pleno sol. A espécie proporcionou plasticidade fenotípica, verificada pelos ajustes das variáveis área foliar total (AFT), área foliar específica (AFE), razão de área foliar (RAF) e razão de massa foliar (RPF) em função dos tratamentos. Ocorreu maior espessamento foliar na condição de pleno sol pelo somatório do maior espessamento da epiderme abaxial e do parênquima esponjoso. A densidade estomática foi maior nas plantas a pleno sol. O número de cloroplastos e seu tamanho foi maior nas telas coloridas, enquanto o maior acúmulo de amido ocorreu a pleno sol e tela vermelha.
\end{abstract}

Palavras-chave: planta medicinal, telas coloridas, qualidade de luz, ultraestrutura foliar.

$\left({ }^{1}\right)$ Receipt for publication in August 27, 2008 and accept in December 12, 2009.

$\left(^{2}\right)$ Departamento de Ciências Biológicas, Universidade Estadual de Santa Cruz, 45662-900 Ilhéus (BA) Brazil. E-mail: larissa@uesc.br $\left(^{*}\right)$ Autora correspondente.

$\left.{ }^{3}\right)$ Universidade Federal de Lavras,Caixa Postal 3037, 37200-000 Lavras (MG) Brazil 


\section{INTRODUCTION}

Plants react to changes that occur in the spectrum of electromagnetic radiation to which they are exposed through alterations in morphology and physiological functions that result in adaptation to different environmental conditions (KASPERBBAUER and HAMilton, 1984). Such alterations are mediated by pigments, known as phytochromes, which have absorption peaks in the red and blue/ultraviolet regions of the spectrum ( $\mathrm{LI}$ et al., 2000). These photoreceptors are able to detect variations in light composition and induce photomorphogenetic responses, either in vivo or in vitro (KIM et al., 2004; MACEDO et al., 2004) that influence growth and development (LeE et al., 1997; Li et al., 2000), morphology (STUEFer and Huber, 1998), leaf and stem anatomy (SChuerger et al., 1997; Lee et al., 2000), distribution of photosynthetic products (KASPERBBAUER, 1987; Brown et al., 1995), photosynthetic efficiency (Kasperbbauer and Peaslee, 1973) and chemical composition (MACEDO et al., 2004).

Specific leaf area (SLA) values depend on the quality of light and vary amongst species. Increases in SLA and reductions in the thickness of the leaf blade under shading conditions are common alterations that confer functional advantages to plants grown in environments with low light intensity (Buisson and LeE, 1993). Thus it is important to know the anatomical and ultra-structural leaf changes that may be somehow related with biomass production.

However, whilst the effects of light quality on plants are well known, the response of different species to light management is variable (KIM et al., 2004), and it is clearly important to treat plants with the correct type of light filters (McMAHON and KeLLY, 1995), especially medicinal plants with economical interests.

A common light quality management is the supplementation with artificial light sources (BROwN et al., 1995) through the use of coloured plastic films (OYAERT et al., 1999), spectral filters (RAJAPAKSE et al., 1992) and reflective coloured mulches (LoUGHRIN and KASPERBBAUER, 2001) to induce physiological responses in plants. Cromatinet ${ }^{\circledR}$ coloured netting modifies the spectrum of the incident radiation in the visible region and enriches the relative content of scattered light such that transmittance of light by the blue netting is in the $400-540 \mathrm{~nm}$ region, whilst that of the red netting is in the 590-760 $\mathrm{nm}$ region (OrEn-Shamir et al., 2001). Although the red:far red ratio (R:FR), which is the main regulatory factor leading to a phytochrome response, is not greatly modified by the use of such nets, the blue:red ratio (B:R) is enhanced by blue netting and reduced by red netting (SHAHAK et al.,
2004). Coloured shade netting not only exhibit special optical properties that allow the control of light, but also have the advantage of influencing the microclimate to which the plant is exposed to (ORENSHAmir et al., 2001) and offer physical protection against excessive radiation, insect pests and environmental changes (SНАнAK et al., 2004).

Ocimum selloi Benth. (Lamiaceae), known as "elixir-paregórico", "alfavaquinha" and "atroveran", is a perennial shrub, native from the southern and south-eastern regions of Brazil. Leaf infusions are widely used in popular medicine as anti-diarrhoeic, anti-spasmodic and anti-inflammatory agents, and the plant is also valued as an insect repellent. Various chemotypes of $O$. selloi have been reported in which the major component of the essential oil, namely methyl chavicol, is accompanied by either methyl eugenol (MARTINS, 1998) or trans-anethol (Moraes et al., 2002), which are commonly found in the leaves of the specie.

Based on previous positive results of coloured shade netting benefits to plants development, we investigated the hypothesis that the light quality of the red-and blue-shade spectrum, rather than the light intensity (full sunlight $v s$. shade conditions), is responsible for the major leaf biomass components of $O$. selloi, related to morphological, physiological and anatomical information.

The objective of the present study was to determine the effects of coloured shade netting on the growth after 90 days and leaf anatomy and ultrastructure of $O$. selloi with the aim of optimising biomass yields of this important medicinal plant.

\section{MATERIALS AND METHODS}

The plantlets with $10 \mathrm{~cm}$ of high of $O$. selloi (voucher specimens were deposited at the herbarium of the Universidade Federal de Lavras with reference number 7474) were planted in November 2005 in10 litter pots spaced $60 \times 60 \mathrm{~cm}$ and submitted to three different light treatments, namely, full sunlight $v$ s coloured shade treatments. Three tents with $8 \times 4 \mathrm{~m}$ and $1.5 \mathrm{~m}$ height were constructed and fully covered with screens. The coloured shading was provided by coloured shade netting (ChromatiNet ${ }^{\circledR} 50 \%$, Polysack Industrias, Leme, SP, Brazil), which presents special optical properties for improving the utilization of solar radiation. For each light treatment, the light intensity was determined at 12:00 $\mathrm{h}$ (moment of higher irradiance) using a Sensor Li-Cor LI-185A quantum meter (Li-Cor, Lincoln, NE, USA). During the experimental period the maximum temperature was $27.86^{\circ} \mathrm{C}$, the average temperature was $21.70{ }^{\circ} \mathrm{C}$, and minimum temperature $17.40{ }^{\circ} \mathrm{C}$ with $199.46 \mathrm{~mm}$ of precipitation. 
The biometric analyses of plants were performed 90 days (flower phase) after the experiment was set. Plant height, stem diameter and petiole length of leaves at the second node below the main inflorescence were determined.

Total leaf area (TLA; $\mathrm{cm}^{2}$ ) was measured using a Li-Cor LI-3100 leaf area meter, from which the specific leaf area (SLA; $\left.\mathrm{cm}^{2} \mathrm{~g}^{-1}\right)$, leaf area ratio $\left(\mathrm{LAR} ; \mathrm{cm}^{2} \mathrm{~g}^{-1}\right)$, and leaf weight ratio (LWR; $\mathrm{g} \mathrm{g}^{-1}$ ) were calculated according to BENINCASA (2003).

Following the determination of leaf growth parameters, the roots, stems, leaves and inflorescences of each plant were separated, packed into individual paper bags, and dried in a fan oven at $70{ }^{\circ} \mathrm{C}$ to constant weight. The root and above ground biomass was determined and the ratio of root: shoot tissues (R:S) was calculated.

Leaves of ten plants grown under different light conditions were examined microscopically. Mature leaves located at the second node below the main inflorescence were excised and fixed with formalin-acetic acid-alcohol solution for $48 \mathrm{~h}$, followed by $70 \%$ ethanol solution.

Paradermic sections of leaf samples obtained from the median region of the leaf blade were freehand cut and stained with $1 \%$ safranin solution. Leaf sections were observed under an Olympus (São Paulo, Brazil) model BX41 light microscope equipped with a Cannon ${ }^{\circledR}$ (São Paulo, Brazil) PowerShot A510 digital camera.

Scanning electron microscopy (SEM) was used to evaluate the thickness of the adaxial and abaxial epidermis, thickness of the palisade and spongy parenchyma, thickness of the leaf blade (transversal sections) and the size and density of stomata.

Leaf sections were cut, fixed with modified Karnovsky solution $[2.5 \%$ glutaraldehyde and $2.5 \%$ formaldehyde in $0.05 \mathrm{M}$ sodium cacodylate buffer $(\mathrm{pH}$ 7.2) containing $0.001 \mathrm{M}$ calcium chloride], washed with sodium cacodylate buffer, immersed in 30\% glycerol and then in liquid nitrogen. The sections were then placed onto a pre-cooled metallic surface, parted using a surgical blade, fixed with $1 \%$ osmium tetroxide, dehydrated in an acetone gradient and dried with a Bal-Tec (Balzers, Liechtenstein) model CPD 030 critical point drier. Sections were then sputtered with gold using a Bal-Tec model SCD 050 evaporator. Microscopic observations and electron micrographs were made using a Nano Technology Systems (Carl Zeiss, Oberkochen, Germany) model Evo ${ }^{\circledR} 40$ VP SEM at an accelerating voltage of $20 \mathrm{kV}$.

Transmission electron microscopy (TEM) was employed to determine the number and area of chloroplasts and starch grains present in the palisade parenchyma cells. Sections were fixed with modified Karnovsky solution as described for SEM, washed with sodium cacodylate buffer and post-fixed with $1 \%$ osmium tetroxide. The sections were transferred to $0.5 \%$ uranyl acetate solution, dehydrated using a gradient of acetone, infiltrated with an increasing gradient of acetone/Spurr's resin mixture and placed into moulds. Following polymerisation for 24 hours in an oven at $70^{\circ} \mathrm{C}$, the resin blocks were trimmed and cut into ultra thin slices $(<100 \mathrm{~nm})$ using a Reichert Jung (Heidelberg, Germany) microtome equipped with a diamond blade. Slices were contrasted with $2 \%$ uranyl acetate followed by $1 \%$ lead acetate for $3 \mathrm{~min}$, and examined using a Zeiss EM 109 microscope.

Digital images were captured using AnalySIS image software (Soft Imaging System GmbH, Münster, Germany) and analysed with a WinCELL Pro software (Regent Instruments, (Sainte-Foy, Québec, Canada).

A totally randomised design was adopted for the investigation, which included three different treatments, seven pots (experimental units) and two plants per repetition. Data were analysed by analysis of variance (one-way ANOVA) and meanvalues were compared using the Tukey's test. Differences were considered significant at $\mathrm{P}<0.05$.

\section{RESULTS AND DISCUSSION}

The average values of light intensity obtained during the study time were $1500 \mu \mathrm{mol} \mathrm{m}^{-2} \mathrm{~s}^{-1}$ (full sunlight), $650 \mu \mathrm{mol} \mathrm{m}^{-2} \mathrm{~s}^{-1}$ (under $50 \%$ blue shading) and $690 \mu \mathrm{mol} \mathrm{m}^{-2} \mathrm{~s}^{-1}$ (under $50 \%$ red shading). The plant height was not different between red- and blueshadding; however, shade-grown plants were significant taller than those grown under direct full sunlight (Table 1). Moreover, the management of light intensity had no effect on the diameter of stems or the length of petioles. Since the stem is characterized by house the vascular tissue, stem diameter is correlated directly with the capacity for transporting water and carbohydrates (StUefer and HUber, 1998), and indirectly with the capacity for storing these metabolites (LeE et al., 1997).

Total dry biomass (exception inflorescences) of plants cultivated under full sunlight was significantly greater than that of those maintained under red or blue shading (Table 1). The response of a plant to shading conditions depends on the complex interaction between quality and quantity of the incident light (LEE et al., 1997). Typically, growth and biomass production are influenced by light intensity, whilst development and morphogenesis are influenced by alterations in light composition (STUEFer and Huber, 1998). 
In general, the vegetative growth of plants maintained under low light intensity is optimised in order to increase light interception and to facilitate photosynthetic processes (KASPerbBauer, 1987). Therefore, the overall improvement in the growth of $O$. selloi plants maintained under full sunlight compared with those under shaded conditions can be explained by the lower light intensity associated with the latter.

The striking reduction in total dry biomass observed in plants grown under blue shading (Table 1) may have resulted from a decrease in the rate of $\mathrm{CO}_{2}$ assimilation (OYAERT et al., 1999). Blue light, either alone or in combination with other types of visible radiation, is known to be a critical factor in the photomorphogenic response of plants (RAJAPAKSE et al., 1992; BROWN et al., 1995), and it has recently been reported (Kim et al., 2004) that there is a reduction in the net photosynthetic rate of plants submitted to blue and blue-far red light treatment.

Although absorbance of light by chlorophyll is maximal in the red portion of the spectrum, biomass production in $O$. selloi was not increased under red shading. This can be explained by the fact that normal plant growth and development can be sustained only by balancing amounts of complementary types of radiation such that plants grown under red shading require supplementation with blue radiation (BROwN et al., 1995).

As shown in Table 1, the root:shoot ratio (R:S) was higher in plants cultivated in full sunlight compared to that of plants cultivated under coloured shading, indicating that the distribution and accumulation of photosynthetic products in the roots is significantly enhanced by intense sunlight. Shading treatments diminished the storage of photosynthetic products in the roots, but the effects of red and blue shading on such accumulation were similar. Normally, environmental variations modify the R:S ratio by altering the distribution of photosynthetic products within the plant (FERREIRA et al., 2004). Although red and far red radiation may control the plant phytochromes and influence the partition between roots and aerial tissues under controlled conditions (KASPERBBAUER, 1987), the alteration in the $\mathrm{R}: S$ ratio observed in $\mathrm{O}$. selloi could be attributed to the variation in light intensity alone.

Despite the decrease in total biomass, and especially of the roots, cultivation of $O$. selloi under red or blue shading led to an increase in the development of inflorescences in comparison with plants maintained under full sunlight. This phenomenon may be explained in terms of a survival strategy, i. e. under unfavourable conditions plants tend to economize energy spent on biomass production in order to support reproductive functions upon which the continued existence of the species depends (LARCHER, 2000). 
TLA decreased in the order red shading $>$ full sunlight $>$ blue shading, whilst both SLA and LAR decreased in the order blue shading $>$ red shading $>$ full sunlight. Regarding LWR, the effects of blue and red shading were similar, but the average values were significantly higher than that produced by full sunlight (Table 2).

Considering that leaf biomass was maximized when plants were maintained under full sunlight, it is likely that the increased TLA exhibited by plants maintained under red shading was due to the expansion of individual leaves, probably influenced by the smaller $\mathrm{R}: \mathrm{B}$ (red:blue) light ratio. A similar finding has been reported for O. basilicum, specimens of which produced greater leaf area and higher fresh biomass yields when cultivated in soil covered with red plastic mulches
(LOUGHRIN and KASPERBBAUER, 2001). In plants maintained under blue shading, for which the B:R light ratio was the highest, leaf expansion was inhibited indicating that $O$. selloi is not tolerant towards this wavelength. According to Li et al. (2000), reduction in leaf size results in a reduction in photosynthetic area and consequently in dry biomass yield. The inhibitory effect of blue shading on the vegetative growth of $O$. selloi has been reported by some authors (OREN-SHAMIR et al., 2001; SHAHAK et al., 2004), whilst reductions in TLA have been observed for Chrysanthemum (OYAERT et al., 1999) and Capsicum (Li et al., 2000) spp. grown under photoselective films and copper sulphate filters. Although variations in leaf area are often associated with variations in the levels of sunlight (GONÇALVES, 2001), in O. selloi this parameter was strongly influenced by the quality of light.

Table 2. Effects of different light regimes on leaf development in Ocimum selloi plants $\left({ }^{1}\right)$

\begin{tabular}{lcccc}
\hline Treatments & TLA $\left(^{2}\right)$ & SLA $\left(^{2}\right)$ & LAR $\left(^{2}\right)$ & LWR $\left(^{z}\right)$ \\
\cline { 2 - 4 } & $\mathrm{cm}^{2}$ & $154.59 \pm 2.4^{\mathrm{C}}$ & $23.81 \pm 0.9^{\mathrm{C}}$ & $0.16 \pm 0.005^{\mathrm{B}}$ \\
Full sunlight & $3592.45 \pm 101.9^{\mathrm{B}}$ & $217.25 \pm 3.3^{\mathrm{B}}$ & $41.35 \pm 1.7^{\mathrm{B}}$ & $0.20 \pm 0.006^{\mathrm{A}}$ \\
Red shading & $4064.96 \pm 155.2^{\mathrm{A}}$ & $233.63 \pm 2.8^{\mathrm{A}}$ & $48.69 \pm 1.9^{\mathrm{A}}$ & $0.21 \pm 0.004^{\mathrm{A}}$ \\
Blue shading & $2401.13 \pm 117.6^{\mathrm{C}}$ & 4.49 & 13.19 & 9.42 \\
Coefficient of variation $(\%)$ & 11.97 & &
\end{tabular}

$\left({ }^{1}\right)$ Results are expressed as mean values \pm standard error $(n=7)$. Within a column, mean values bearing different superscript letters were significantly different (Tukey's test; $\mathrm{p}<0.05)$.

( $\left.{ }^{2}\right)$ TLA - total leaf area; SLA - specif leaf area; LAR - leaf area ratio; LWR - leaf weight ratio.

The SLA is inversely related to the thickness of the leaf blade, and alterations in its value reflect changes in leaf structure. Whilst SLA values depend on the quality of light and vary amongst species, increases in SLA and reductions in the thickness of the leaf blade under shading conditions are common alterations that confer functional advantages to plants grown in environments with low light intensity (Buisson and LeE, 1993). This was demonstrated to be the case for $O$. selloi plants maintained under red or blue shading, the leaves of which were significantly thinner than those of plants cultivated in full sunlight. For blue-grown plants, however, the larger SLA value was compensated by a reduced TLA resulting in a smaller leaf biomass. Species of Chrysanthemum and Capsicum maintained under photoselective plastic also exhibited reduced SLA values (Li et al., 2000), whilst in Hopea spp. the quality of light was reported to have no effect on SLA (LEE et al., 1997),

LAR reflects the magnitude of the photosynthetic area (BENINCASA, 2003). The increased LAR values obtained for $O$. selloi grown under blue shading indicate that these plants required a larger leaf area for the production of one gram of dry matter than those grown under red shading or in full sunlight. According to
BENINCASA (2003), alterations in LAR values may be understood, within certain limits, as the capacity of a species to adapt to different light conditions.

O. selloi plants grown under shading presented larger LWR values than those grown under full sunlight, demonstrating that in the former situation some of the photosynthetic products were retained in the leaves, whilst in the latter these products were more efficiently exported to other tissues. In fact, the capacity to export photoassimilates from leaves to other parts may be a genetic characteristic that can be influenced by environmental changes, including the spectral quality of light (BENINCASA, 2003).

Examination by light microscopy of the paradermic leaf sections of plants grown under coloured shading revealed that the anticlinal cell walls of the adaxial and abaxial epidermis were more irregular than those of plants grown in full sunlight (Fig. 1). Measurements of transversal leaf sections under SEM revealed that, under all light regimes, the adaxial epidermis was thicker than the abaxial epidermis and the spongy parenchyma was thicker than the palisade parenchyma (Table 3). 

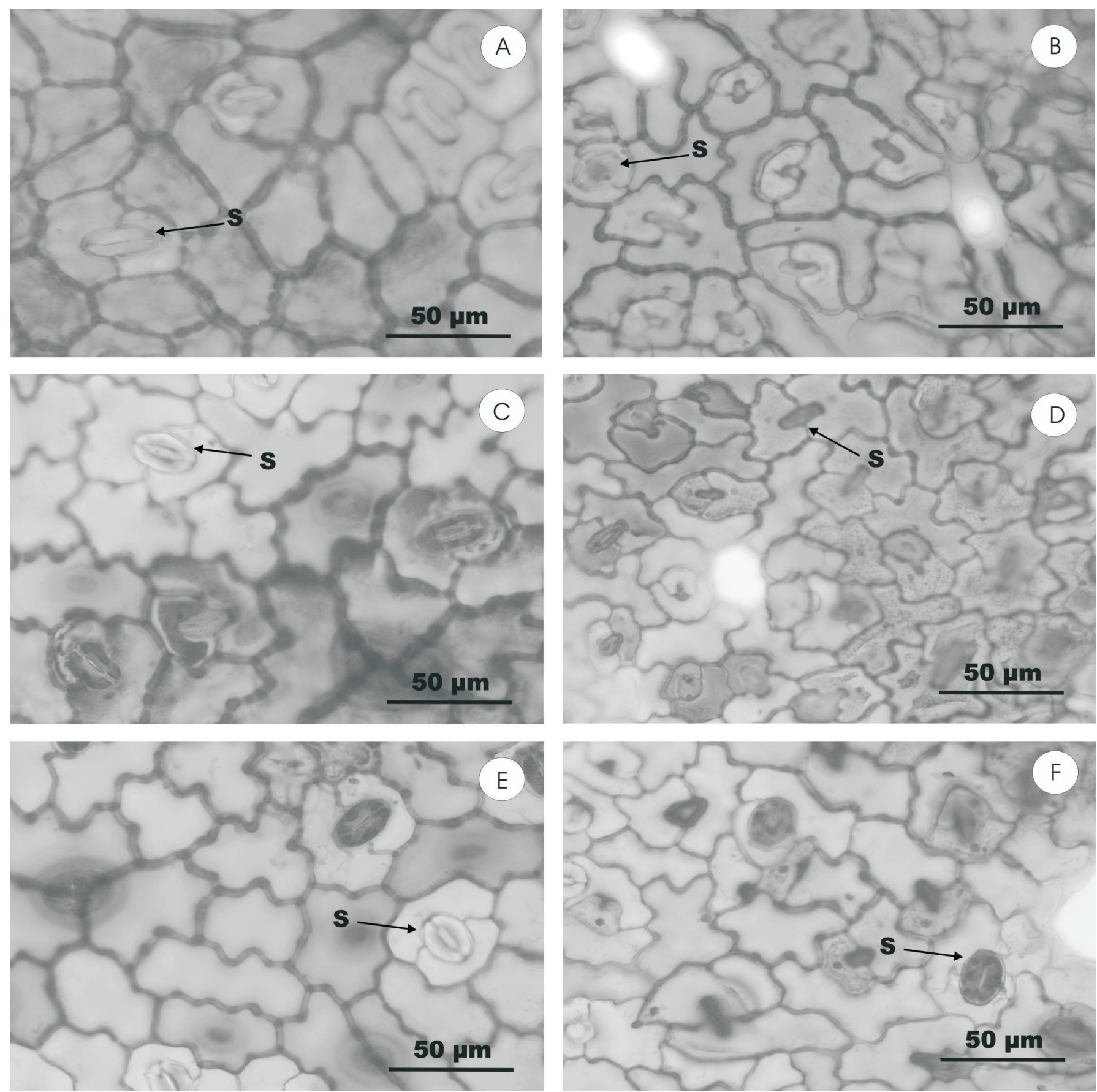

Figure 1. Photomicrographs of the leaf epidermis of Ocimum selloi showing the adaxial (A, C and E) and abaxial (B, D and F) surfaces in plants maintained under full sunlight (A and B), red shading (C and D) or blue shading (E and F). Red and blue shading was provided by $50 \%$ ChromatiNet $^{\circledR}$ coloured plastic netting. Arrows labelled S indicate stomata. 

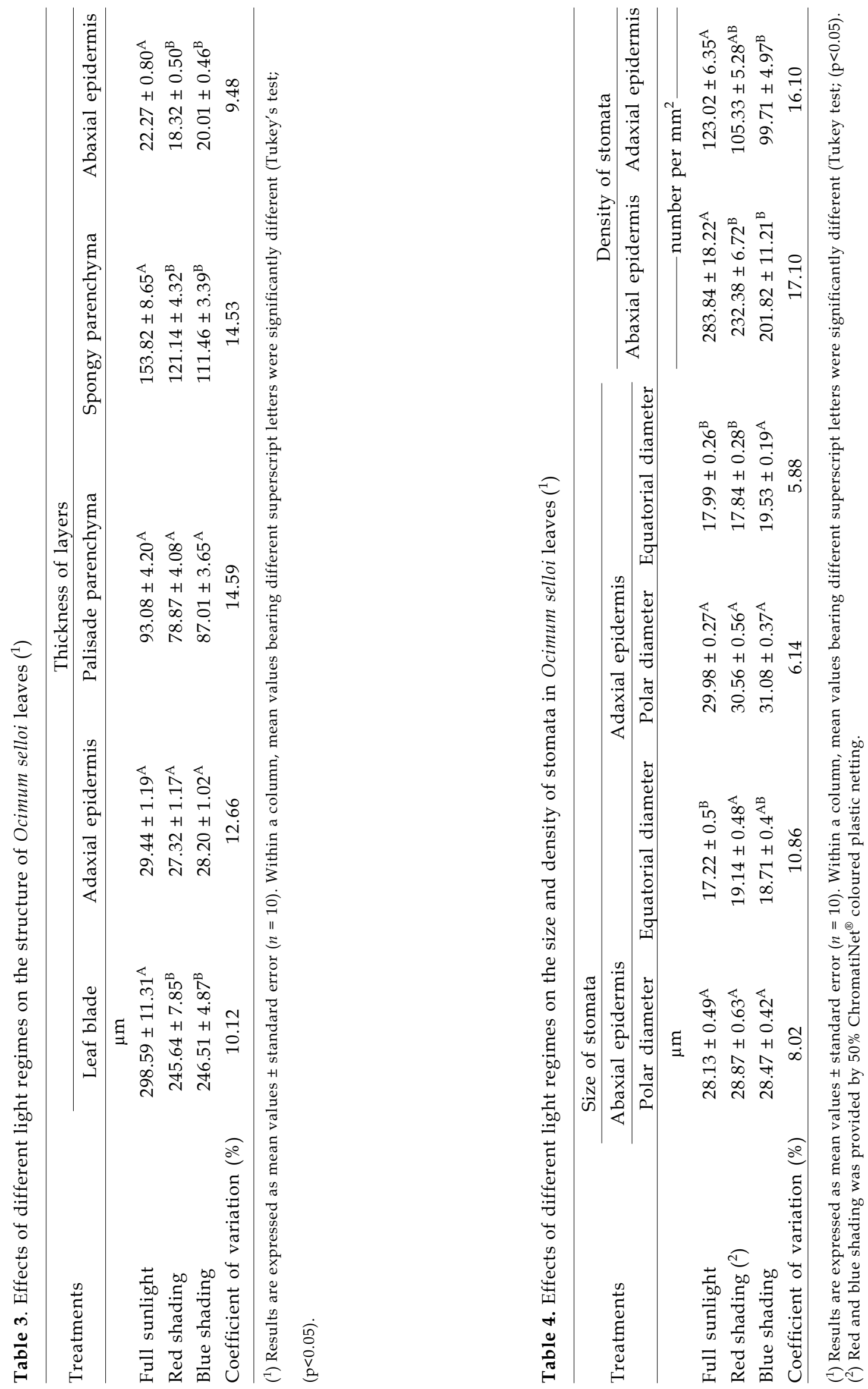

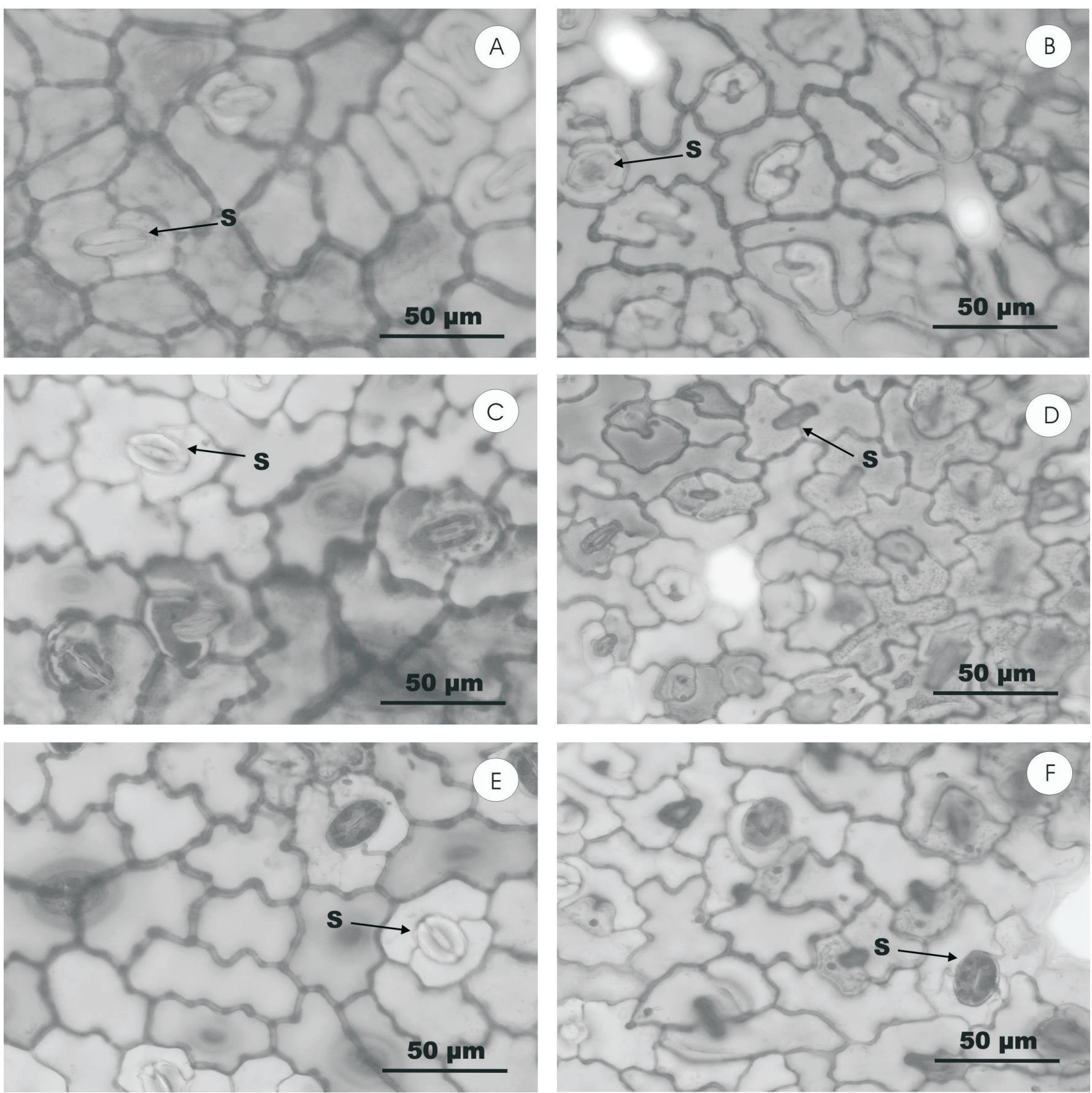

Figure 2. SEM photomicrographs of transverse sections of leaves of Ocimum selloi (A, C and E), and TEM photomicrographs showing aspects of the chloroplasts $(B, D$ and $F)$, in plants maintained under full sunlight (A and $B)$, red shading $(C$

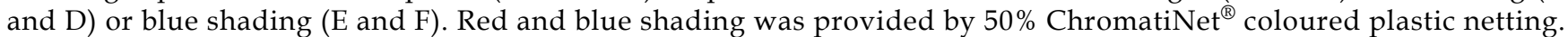
Arrows indicate the cell wall (CW), starch grains (SG) and chloroplasts (CL). 
Table 5. Effects of different light regimes on chloroplasts and starch grains in Ocimum selloi palisade parenchyma cells $\left({ }^{1}\right)$

\begin{tabular}{|c|c|c|c|c|}
\hline \multirow[t]{2}{*}{ Treatments } & \multicolumn{2}{|l|}{ Chloroplasts } & \multicolumn{2}{|c|}{ Chloroplast starch grains } \\
\hline & Number & Area & Number & Area \\
\hline & & $\mu \mathrm{m}^{2}$ & & $\mu \mathrm{m}^{2}$ \\
\hline Full sunlight & $11.40 \pm 0.98^{\mathrm{B}}$ & $4.68 \pm 0.12^{\mathrm{B}}$ & $1.6 \pm 0.16^{\mathrm{A}}$ & $1.18 \pm 0.08^{\mathrm{A}}$ \\
\hline Red shading $^{2}$ & $15.90 \pm 1.12^{\mathrm{A}}$ & $6.49 \pm 0.43^{\mathrm{A}}$ & $1.5 \pm 0.16^{\mathrm{A}}$ & $1.09 \pm 0.21^{\mathrm{A}}$ \\
\hline Blue shading ${ }^{2}$ & $18.20 \pm 0.96^{\mathrm{A}}$ & $7.06 \pm 0.51^{\mathrm{A}}$ & $0.8 \pm 0.20^{\mathrm{B}}$ & $1.10 \pm 0.29^{\mathrm{A}}$ \\
\hline Coefficient of variation (\%) & 21.34 & 17.22 & 43.16 & 49.99 \\
\hline
\end{tabular}

$\left({ }^{1}\right)$ Results are expressed as mean values \pm standard error $(n=10)$. Within a column, mean values bearing different superscript letters were significantly different (Tukey test; $\mathrm{p}<0.05$ ).

$\left({ }^{2}\right)$ Red and blue shading was provided by $50 \%$ ChromatiNet $^{\circledR}$ coloured plastic netting.

The thicknesses of the adaxial epidermis and the palisade parenchyma were unaltered by shading, but plants exposed to full sunlight showed an increase in thickness of the abaxial epidermis and spongy parenchyma resulting in the formation of a thicker leaf blade (Figure $2 \mathrm{a}, \mathrm{c}, \mathrm{e}$ ).

For plants maintained under shading conditions, a reduction in leaf thickness appears to be a common phenomenon that may be attributed to diverse factors including an increase of the R:FR (red:far red) light ratio (Kasperbbauer and Peaslee, 1973) and a decrease in light intensity (BUISSON and LEE, 1993). Since there were no variations in the R:FR light ratio in the experiments performed with $O$. selloi, the increased leaf thickness observed in plants grown in sunlight resulted exclusively from the variation in light intensity. These results corroborate those found by LeE et al. (2000), who reported that changes in the quality of light did not significantly affect the thickness of the leaf blade or alter the structure of the mesophyll layer.

SEM examination revealed that the epidermal layers of $O$. selloi leaves contained diacytic stomata of equal size and positioned at the same level as other epidermal cells (Table 4). Although stomata were observed in both the lower and upper epidermis, their density was greater on the abaxial surface (hypoamphistomatal leaves; Fig. 1). Moreover, the density of stomata was significantly greater in leaves of plants grown in full sunlight (Table 4), a finding that is in agreement with that of BUISSON and LEE (1993), who reported a reduction in stomatal density in plants maintained under neutral and filtered shading compared with those cultivated in full sunlight, and of LEE et al (1997), who found a higher stomatal density in plants of Hopea odorata maintained under strong light intensity. In the case of $O$. selloi, the polar diameter of the stomata in both epidermal layers was not influenced by light treatment whereas the equatorial diameter varied according to the quality of the light such that red shading increased the diameter of abaxial stomata whilst blue shading increased the diameter of adaxial stomata.

SEM examination of transverse leaf sections revealed a dorsiventral structure and a uniseriate epidermis. The mesophyll consisted of one layer of palisade parenchyma cells and four to five layers of spongy parenchyma cells (MARTINS, 1998; GONÇALVES, 2001). Additionally, cells of the adaxial epidermis were observed to be larger than those of the abaxial layer. Variations in the shape of epidermal cell walls following exposure of Mikania glomerata to different photoperiod treatments have been previously reported (CASTRO et al., 2005).

Chloroplasts were generally observed near to the cell walls (Figure 2a, d, f). The number and size of chloroplasts located in cells of the palisade parenchyma was significantly larger in plants grown under red and blue shading compared with plants maintained under full sunlight (Table 5). These results can be explained by the fact that the leaves of shaded plants are thinner and contain larger pigment-rich chloroplasts.

The number of starch grains in the chloroplasts was greater in plants grown under red shading and full sunlight, whilst the size of the grains was not influenced by the light treatment (Table 5; Figure 2b, d, f). These findings confirm those reported by Kasperbbauer and Hamilton (1984) and LeONG et al. (1985). Red light is essential for the development of the photosynthetic apparatus and has been shown to increase the accumulation of starch in many plant species by the inhibition of translocation of photo-assimilates to other tissues (KASPERBBAUER and HAMilton, 1984; SCHUERGER et al., 1997). 


\section{CONCLUSION}

Various modifications in the anatomy and morphology of $O$. selloi, including plant height, total and organ-specific (roots, stems, leaves and inflorescences) dry biomass, R:AP ratio, LWR, leaf thickness, stomatal density and size of chloroplasts, resulted from the alteration of light intensity. However, TLA, SLA, LAR, and the number of chloroplasts and starch grains were influenced by the quality of the incident radiation ( $R$ :B light ratio).

\section{ACKNOWLEDGMENTS}

The authors are grateful to Polysack Indústrias (Leme, SP, Brazil) for the coloured shade netting donation, to Fundação de Amparo à Pesquisa de Minas Gerais for financial support and to the Conselho Nacional de Desenvolvimento Científico e Tecnológico (CNPq) for one scientific productivity fellowship.

\section{REFERENCES}

BENINCASA, M.M.P. Análise de crescimento de plantas. $2^{\text {nd }}$ Ed. FUNEP: Jaboticabal, 2003. 41p.

BROWN, C.S.; SCHUERGER, A.C.; SAGER, J.C. Growth and photomorphogenesis of pepper plants under red lightemitting diodes with supplemental blue or far-red lighting. J. American Society of Horticultural Science, v. 120, p. 808813, 1995.

BUISSON, D.; LEE, D.W. The developmental responses of papaya leaves to simulated canopy shade. American Journal of Botany, v.80, p. 947-952, 1993.

CASTRO, E.M.; PINTO, J.E.B.P.; MELO, H.C.; SOARES, A.M.; ALVARENGA, A.A.; LIMA JÚNIOR, E.C. Aspectos anatômicos e fisiológicos de plantas de guaco submetidas a diferentes fotoperíodos. Horticultura Brasileira, v.23, p.846-850, 2005.

FERREIRA, M.M.; MOTA, M.B.; PINTO, J.E.P.B.; CASTRO, E.M. Crescimento e alocação e alocação de biomassa de planas de vinca (Catharanthus roseus (L.) G. Don) em função da adubação orgânica e época de colheita. Revista Brasileira de Plantas Medicinais, v.6, p.72-76, 2004.

GONÇALVES, L.A. Ontogenia dos tricomas glandulares e influência da radiação solar no desenvolvimento e no teor de óleo essencial de Ocimum selloi Benth. (Lamiaceae). Viçosa. 2001. 95p. (MSc Dissertation). Universidade Federal de Viçosa.

KASPERBAUER, M.J. Far-red light reflection from green leaves and effects on phytochrome-mediated assimilate partitioning under field conditions. Plant Physiology, v.8, p.350-354, 1987.
KASPERBAUER, M.J.; HAMILTON, J.L. Chloroplast structure and starch grain accumulation in leaves that received different red and far-red levels during development. Plant Physiology, v.74, p.967-970, 1984.

KASPERBAUER, M.J.; PEASLEE, D.E. Morphology and photosynthetic efficiency of tobacco leaves that received endof-day red or far red light during development. Plant Physiology, v.52, p.440-442, 1973.

KIM, S-J.; HAHN, E-J.; HEO, J.; PAEK, K-Y. Effects of LEDs on net photosynthetic rate, growth and leaf stomata of chrysanthemum plantlets in vitro. Scientia Horticulturae, v.101, p.143-151, 2004.

LARCHER, W. Ecofisiologia Vegetal. RIMA: São Carlos, 2000. 319p.

LEE, D.W.; OBERBAUER, S.F.; KRISHNAPILAY, B.; MANSOR, M.; MOHAMAD, H.; YAP, S.K. Effects of irradiance and spectral quality on seedling development of two Southeast Asian Hopea species. Oecologia, v.110, p.1-9, 1997.

LEE, D.W.; OBERBAUER, S.F.; JOHNSON, P.; KRISHNAPILAY, B.; MANSOR, M.; MOHAMAD, H.; Yap, S.K. Effects of irradiance and spectral quality on leaf structure and function in seedlings of two Southeast Asian Hopea (Dipterocarpaceae) species. American Journal of Botany, v.87, p.447-455, 2000.

LEONG, T.; GOODCHILD, D.J.; ANDERSON, J.M. Effect of light quality on the composition, function and structure of photosynthetic thylakoid membranes of Asplenium australicum (Sm.) Hook. Plant Physiology, v.78, p.561-567, 1985.

LI, S.; RAJAPAKSE, N.C.; YOUNG, R.E.; OI, R. Growth responses of chrysanthemum and bell pepper transplants to photoselective plastic films. Scientia Horticulturae, v.84, p.215$225,2000$.

LOUGHRIN, J.H.; KASPERBAUER, M.J. Light reflected from colored mulches affects aroma and phenol content of sweet basil (Ocimum basilicum L.) leaves. Journal of Agriculture and Food Chemistry, v.49, p.331-1335, 2001.

MACEDO, A.F.; LAGE, C.L.; ESQUIBEL, M.A.; SOUZA, M.M.; SILVA, K.L.; NIERO, R.; CECHINEL-FILHO, V. Preliminary phytochemical and pharmacological studies on plantlets of Alternanthera brasiliana cultured under different spectral quality of lights. Acta Farmaceutica Bonaerense, v.23, p.515-519, 2004.

MARTINS, E.R. Estudos em Ocimum selloi Benth: isoenzimas, morfologia e óleo essencial. In: MING, L.C.; SCHEFFER, M.C.; CORREAA JÚNIOR, C.; BARROS, I.B.I.; MATTOS, J.K.A. (Eds.) Plantas medicinais e aromáticas condimentares: avanços na pesquisa agronômica, v. 2. Botucatu: UNESP, 1998. p.97-126.

MCMAHON, M.J.; KELLY, J.W. Anatomy and pigments of chrysanthemum leaves developed under spectrally selective filters. Scientia Horticulturae, v.64, p.203-209, 1995.

MORAES, L.A.S.; FACANALI, R.; MARQUES, M.O.M.; MING, L.C.; MEIRELES, M.A.A. Phytochemical characterization of essential oil from Ocimum selloi. Anais da Academia Brasileira de Ciências, v.74, p.183-186, 2002. 
OREN-SHAMIR, M.; GUSSAKOVSKY, E.E.; SPIEGEL, E.; NISSIM-LEVI, A.; RATNER, K.; GILLER, Y.E.; SHAHAK, Y. Colored shade nets can improve the yield and quality of green decorative branches of Pittosporum variegatum. Journal of Horticultural Science and Biotechnology, v.76, p.353-361, 2001.

OYAERT, E.; VOLCKAERT, P.C.; DEBERGH, P.C. Growth of chrysanthemum under coloured plastic films with different light qualities and quantities. Scientia Horticulturae, v.79, p.195-205, 1999.

RAJAPAKSE, N.C.; POLLOCK, R.K.; MCMAHON, M.J.; KELLY, J.W.; YOUNG, R.E. Interpretation of light quality measurements and plant response in spectral filter research. HortScience, v.27, p.1208-1211, 1992.

SCHUERGER, A.C.; BROWN, C.S.; STRYJEWSKI, E.C. Anatomic features of pepper plants (Capsicum annuum L.) grown under red light-emitting diodes supplemented with blue or far-red light. Annals of Botany, v.79, p.273-282, 1997.

SHAHAK, Y.; GUSSAKOVSKY, E.E.; GAL, E.; GANELEVIN, R. Colornets: crop protection and light-quality manipulation in one technology. Acta Hort. 659, 143-151. 2004. Available at http://www.actahort.org/books/659/659_17.htm Accessed in 16th May 2006.

STUEFER, J.F.; HUBER. H. Differential effects of light quantity and spectral light quality on growth, morphology and development of two stoloniferous Potentilla species. Oecologia, v.117, p.1-8, 1998. 